\title{
Nitrogen Inputs by Precipitation in the Nigerian Savanna
}

\author{
I. F. Adeniyi \\ Hydrobiology Section (Laboratory of Limnology), Zoology Department, Obafemi Awolowo University, Ile-Ife, \\ Osun State, Nigeria
}

\begin{abstract}
Inorganic nitrogen input via direct bulk precipitation was measured, and the relation between the different nitrogen species and rainfall characteristics determined over three rainy seasons at Shagunu, a remote, sparsely populated, non-industrialized site in the northern Guinea savanna of Nigeria. Nitrogen concentration per event rain varied very widely $\left(\mathrm{NH}_{4}^{+}-\mathrm{N}=0-3738 \mu \mathrm{g} \mathrm{dm}{ }^{-3}, \mathrm{NO}_{3}^{-}-\mathrm{N}=0-5389\right.$ $\mu \mathrm{g} \mathrm{dm}{ }^{-3}$ ) with amount-weighted mean values of $269 \mu \mathrm{g} \mathrm{dm}{ }^{-3} \mathrm{NH}_{4}^{+}-\mathrm{N}$ and $76 \mu \mathrm{g} \mathrm{dm}^{-3} \mathrm{NO}_{3}^{-}-\mathrm{N}$, and a positively skewed frequency distribution for each species. The mean annual total nitrogen deposition of $3.3 \mathrm{~kg} \mathrm{ha}^{-1}$ (range $=2.85-3.47 \mathrm{~kg} \mathrm{ha}^{-1}$ ) comprised of $79 \%$ $\mathrm{NH}_{4}{ }^{-}-\mathrm{N}$ and $21 \% \mathrm{NO}_{3}^{-}-\mathrm{N}$. This is about $12 \%$ of the estimated total nitrogen input into the Nigerian grazing savanna and $25 \%$ of the estimated nitrogen loss from it through annual bush burning. Compared with the available records for West Africa the mean average input is rather low; it is similar with figures for the remote parts of the world with little or no anthropogenic contribution. All probable accounts pointed to a low nitrogen background, relatively low annual precipitation (due to a peculiar topographic effect on the study site) and the fact that rain water nitrogen was predominantly of terrestrial origin. Monographs for the estimation of $\mathrm{NO}_{3}^{-}-\mathrm{N}$ concentrations from the amount of event rainfall through the rainy season were provided. Multiple regression equations for the estimation of nitrogen inputs in West Africa from rainfall amount, latitudinal position, and distance away from the sea were also provided.
\end{abstract}

\section{Introduction}

Nitrogen compounds are among the most important condensation nuclei upon which atmosphere precipitation is effected (Hutchinson, 1957). Apart from this, the composition and levels of precipitated nitrogen is of interest for many other reasons. Precipitated nitrogen is an integral part of the global nitrogen cycle (Soderlund \& Svensson, 1976), it gives an insight into many aspects of the general character of the air mass, and in many industrialized parts of the world it is of great concern with regard to both soil and water acidification, eutrophica-tion and some environmental health hazards (National Academy of Sciences, 1969). Precipitation is a major means by which many nitrogen compounds lost into the atmosphere and/or produced within it are returned to the earth's surface. Such inputs can be crucial in parts of the world (such as tropical savanna) where soils are generally inherently infertile and biological productivity is largely limited by the supply of plant available nitrogen.

Ammonia (the most reduced form of nitrogen) and nitrate (the most oxidized form of nitrogen) were the first trace forms to be studied thoroughly in air and rain water (Junge, 1963) and up to now, studies of the nitrogen cycle through the atmosphere have been based largely on their measurements. Ammonia is the only common soluble basic gas in the atmosphere and, perhaps, the most obvious agent in the atmospheric interaction between global nitrogen and sulphur cycles (Gras, 1983). The nitrate concentration in rain may be regarded as an indicator of important electrical processes occurring during the formation of rain (Reiter \& Reiter, 1958) while the molar ratio of $\left[\mathrm{NO}_{3}^{-}\right]$: $\left[\mathrm{NH}_{4}^{+}\right]$is a measure of the acidity or alkalinity of precipitation contributed by nitrogen cycling (Galbally \& Gillett, 1988). Ammonia, nitrate and organic nitrogen are also the major forms in which fixed nitrogen occurs in most environments. They are the most important forms in which nitrogen is fixed in biological processes, hence their importance in agriculture.

Whereas much information is now available on the precipitation of nitrogen in some parts of the world, notably Europe and North America, the information available for other parts, especially the tropics is still very limited and scattered. This has made global nitrogen budgets difficult and/or uncertain (Robertson \& Rosswall, 1980). In West Africa, the limited published works include those of Berg et al,. (1980), Isichei et al., (1990), Isichei 


\section{West Africa Journal of Applied Ecology (WAJAE) -ISSN: 0855-4307 \\ Volume 9 (Jan - Jun 2006) \\ Www.wajae.org}

(1995), Jones (1960, 1971, 1972), Jones \& Bromfield (1970), Nye (1961), Servant et al., (1984), Thornton (1965), and Villencourt (1975).

The present work was undertaken to provide information on ammonium and nitrate inputs via direct bulk precipitation in a remote, sparsely populated and non-industrialized area in the Guinea savanna zone of Nigeria. Information was also obtained on the relationship between the investigated nitrogen forms and some rainfall characteristics as well as some water quality parameters ( $p \mathrm{H}$ and conductivity).

Study area

\section{Materials and methods}

Detailed accounts of the general features of the study area, the Kainji Lake area of Nigeria, have been given by a number of workers (Adeniyi, 1978; Afolayan, 1982; El-Zarka, 1973; Henderson, 1973; Imevbore, 1970). The area is on the border of the sub-Sudan and northern Guinea savanna of Nigeria (Clayton, 1957; Keay, 1959) or Sudanian woodland (White, 1983). It falls within the moist-dry monsoon type of the hot equatorial tropical climate (Papadakis, 1965). The climate of the area is governed by two air masses; the rain-bearing south-west winds from the Atlantic Ocean and the dry and dusty north-easterly trade winds from the Sahara. The latter blow from mid-November to mid-March while the southerly maritime westerlies prevail for the rest of the year. Line squalls (with wind speeds reaching up to $90 \mathrm{~km} \mathrm{~h}^{-1}$ ) and violent thunder storms are frequent at the beginning and end of the rainy season.

In the study area, March-May is taken as the early rainy season, June-August as the mid-season and September through October as the late rainy season, while June-September is the growing season. The site of rain collection was the meteorological station at the Shagunu Field Station (Niger State) of the Nigerian National Institute of Freshwater Fisheries Research (formerly Kainji Lake Research Institute, Nigeria). It is an open site located away from traffic on a promontory at approximately $150 \mathrm{~m}$ above mean sea level $\left(10^{\circ} 21^{\prime} \mathrm{N}, 004^{\circ} 28^{\prime} \mathrm{E}\right)$ on the western shore of Lake Kainji at about $440 \mathrm{~km}$ from the Atlantic coast. Information on the rainfall regime and some other meteorological characteristics of the field station is presented in Fig. 1. The area can be taken as typical of the middle belt of Nigeria, and/or at least that part of Nigerian savanna characterized with high frequency of single-peak rainfall regime and/or 160-200 rainfall days in the year. 


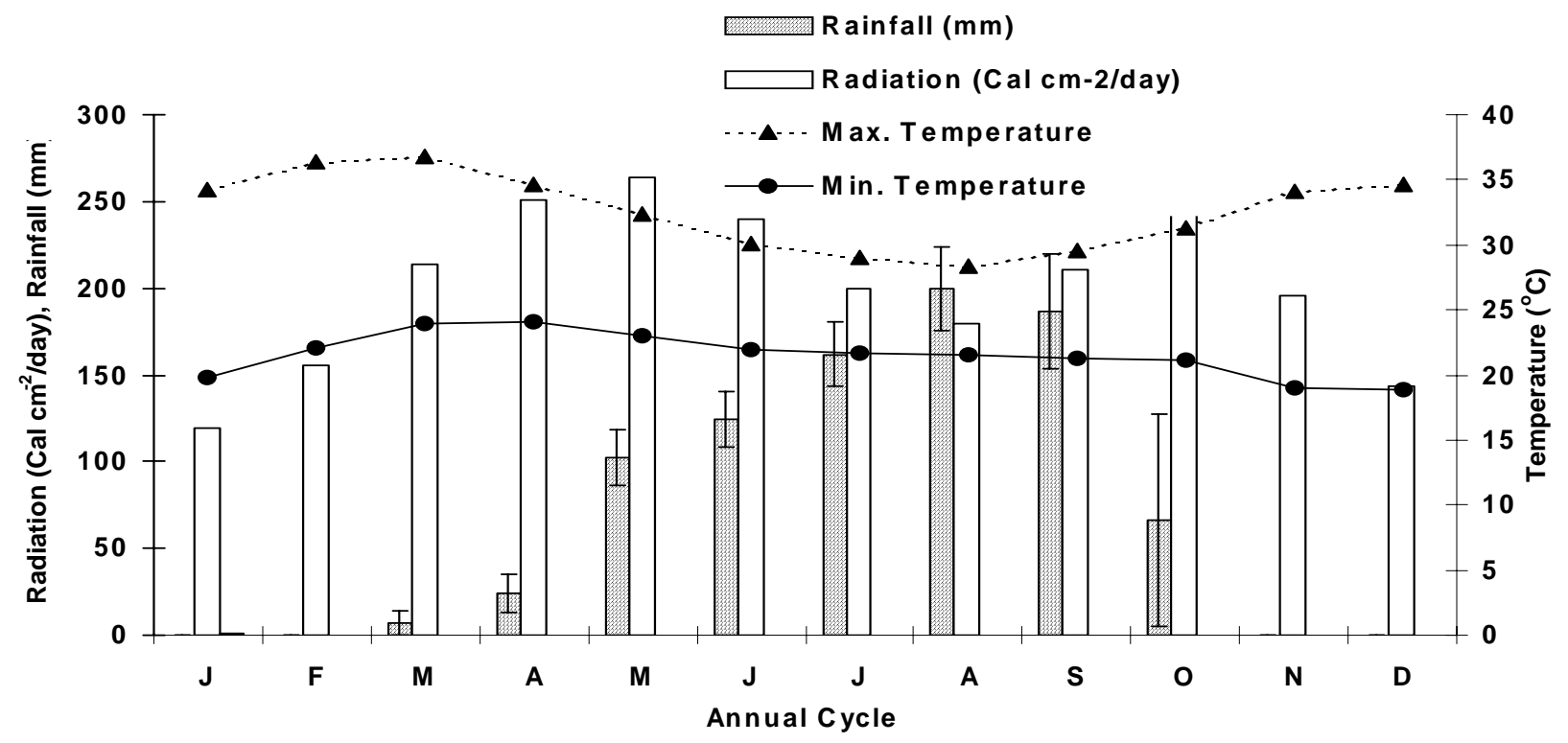

Fig. 1 . The climate diagram of Shagunu Research Station $\left(10^{\circ} 21^{\prime} \mathrm{N}, 004^{\circ} 28^{\prime} \mathrm{E}\right.$, Northwest, Nigeria

Sample collection and chemical analysis

Direct bulk precipitation (Whitehead \& Feth, 1964) was collected after each rain event (there was rarely more than one event per day) for nearly three rainy seasons (May 1992-August 1995) at the collection site. The collection of adequate sample of each rain event was made possible using a funnel and plastic bottle mounted and supported on a concrete pillar about $0.5 \mathrm{~m}$ above the ground surface (to avoid the effect of ground splashing) within the meteorological station. The actual amount of precipitation event was measured directly with the standard rain gauge while the duration of fall was estimated for each sample from the hyetogram (the automatic combined rainfall amount and duration recorder) at the meteorological station. The time interval between two successive rain events/samples (hereafter referred to as IBRE) was estimated to the nearest whole day.

Sub samples for nitrogen determinations were analyzed within the analytical holding time of each parameter or preserved with chloroform for short-term storage (Allen et al., 1974). Ammonium-nitrogen $\left(\mathrm{NH}_{4}^{+}-\mathrm{N}\right.$ and soluble $\mathrm{NH}_{3}$ ) was determined colorimetrically by the indophenol method at $635 \mathrm{~nm}$ (Chaney \& Marbach, 1962) and nitrate-nitrogen $\left(\mathrm{NO}_{3}-\mathrm{N}\right)$ by the phenol disulphonic acid method at $410 \mathrm{~nm}$ (APHA, 1980). The combined concentration of these two nitrogen forms $\left(\mathrm{NH}_{4}{ }^{+}-\mathrm{N}+\mathrm{NO}_{3}{ }^{-}-\mathrm{N}\right)$ was taken as total inorganic nitrogen (TN). The areal nitrogen deposition per rain event (sample) was calculated from the corresponding values of both nitrogen concentration and rainfall amount according to Junge (1963) as follows:

Deposition $\left(\mathrm{kg} \mathrm{ha}^{-1}\right)$

$$
=\frac{\text { Concentration }\left(\mathrm{mg} \mathrm{dm}^{-3} \times \text { rain amount }(\mathrm{mm})\right.}{100}
$$

The specific electrical conductivity of samples was measured immediately after sample collection with a conductivity meter (series 3 of Evershed Vignole Ltd, UK) which gave reading directly in microsiemens per 


\section{West Africa Journal of Applied Ecology (WAJAE) -ISSN: 0855-4307 \\ Volume 9 (Jan - Jun 2006) \\ www.wajae.org}

centimeter $\left(\mathrm{mS} \mathrm{cm}^{-1}\right)$ at $2{ }^{\circ} \mathrm{C}$ while sample $p \mathrm{H}$ was measured using a Lovibond $p \mathrm{H}$ comparator and appropriate disc and indicator solution. Altogether 123 event rain samples were collected and analyzed, they comprised of 41, 47 and 35 samples, respectively, for the 3 years of study (in a typical year there are about 50 rainy days in the study area).

\section{Nitrogen concentration and deposition}

\section{Results}

Rainfall characteristics and nitrogen levels in event rains varied widely (Table 1). For each nitrogen species, the frequency distribution pattern of concentration was positively skewed (i.e. skewed towards higher concentrations) with mode, median, and amount-weighted mean values lower than the arithmetic mean. The concentration of $\mathrm{NO}_{3}^{-}-\mathrm{N}$ was below detection limit $\left(0.20 \mathrm{mg} \mathrm{dm}{ }^{-3}\right)$ in about $10 \%$ of the sample population while in about $40 \%$ of the population values were below $5 \mu \mathrm{g} \mathrm{dm}^{-3}$. On the other hand, about $10 \%$ of the samples had values above $300 \mu \mathrm{g} \mathrm{dm}^{-3}$. Concentra-tions were generally much higher at the beginning and end of the rainy season than during the mid season period. The arithmetic mean ( \pm standard error) for the three periods of the season were $381 \pm 21 \mu \mathrm{g} \mathrm{dm}^{-3}, 87 \pm 17 \mu \mathrm{g} \mathrm{dm}{ }^{-3}$, and $140 \pm 35 \mu \mathrm{g} \mathrm{dm}{ }^{-3}$ for early rainy season, mid season, and late rainy season, respectively (ANOVA F-Ratio $=3.25$, $\mathrm{df}=2 \alpha 121, \mathrm{P}=0.041$ ).

TABLE 1

Descriptive statistics of event rainfall characteristics and nitrogen concentrations in the study site (Shagunu Research station, Nigeria)

$\begin{array}{llllclll}\text { Rain parameter } & \text { Min. } & \text { Max. } & \text { Median } & \text { Mean } \pm \text { S.E.M. Weighted mean } & \text { Skewness } & \text { Kurtosis } \\ & & & & & - & 1.33 & 1.06 \\ \text { Rain amount (mm) } & 0.8 & 62.7 & 10.9 & 16.2 \pm 1.3 & - & 7.0 & 49.2 \\ \text { IBRE (days) } & 1 & 157 & 3 & 6 \pm 2 & 6.35 & 0.17 & -0.86 \\ \mathrm{pH}(\mathrm{pH} \text { unit) } & 6.0 & 7.05 & 6.40 & 6.39 \pm 0.02 & 19.7 & 6.52 & 54.33 \\ \left.\mathrm{Conductivity}(\mu \mathrm{S} \mathrm{cm})^{-1}\right) & 6.0 & 250.0 & 22.5 & 24.3 \pm 2.2 & 76 & 9.20 & 92.5 \\ \mathrm{NO}_{3}^{-}-\mathrm{N}\left(\mu \mathrm{gm}^{-3}\right) & <0.02 & 5389 & 49 & 160 \pm 44.2 & 264 & 3.35 & 16.2 \\ \mathrm{NH}_{4}^{+}-\mathrm{N}\left(\mu \mathrm{g} \mathrm{dm}^{-3}\right) & <0.02 & 3738 & 210 & 360 \pm 44.2 & 345 & 4.18 & 22.75 \\ \text { Total } \mathrm{N}\left(\mu \mathrm{g} \mathrm{dm}^{-3}\right) & 3.0 & 5830 & 341 & 520 \pm 67.0 & & \end{array}$

IBRE = Interval between rain events, $\mu \mathrm{g} \mathrm{dm}{ }^{-3}=\mu \mathrm{g} \mathrm{L^{-1 }}$

S.E.M. = Standard error of mean

The concentrations of $\mathrm{NH}_{4}^{+}-\mathrm{N}$ were characterized by higher values and variability than that of $\mathrm{NO}_{3}^{-}-\mathrm{N}$. In about $40 \%$ of the population, $\mathrm{NH}_{4}^{+}-\mathrm{N}$ values were above $300 \mu \mathrm{g} \mathrm{dm}^{-3}$ while in about $10 \%$ of the population levels were even above $1000 \mu \mathrm{g} \mathrm{dm}^{-3}$. Over the three periods of the rainy season mean concentration (arithmetic means and standard error) fell from $429 \pm 115 \mu \mathrm{g} \mathrm{dm}{ }^{-3}$ (early season) through $393 \pm 70 \mu \mathrm{g} \mathrm{dm}^{-3}$ (mid season) to $256 \pm 64 \mu \mathrm{g} \mathrm{dm}{ }^{-3}$ (late season). Like $\mathrm{NH}_{4}^{+}-\mathrm{N}$, the concentration of total nitrogen per event decreased steadily throughout the season. The mean concentration for early rains was higher than that of late rains by a factor of 


\section{West Africa Journal of Applied Ecology (WAJAE) -ISSN: 0855-4307 \\ Volume 9 (Jan - Jun 2006) \\ Www.wajae.org}

about 2. In all cases concentrations above $1000 \mu \mathrm{g} \mathrm{dm}{ }^{-3}$ were associated with rainfall less than $5 \mathrm{~mm}$ while those below detection were associated mainly with rains above $400 \mathrm{~mm}$.

The relationship between rain water $\mathrm{NH}_{4}^{+}-\mathrm{N}$ and $\mathrm{NO}_{3}{ }^{-}-\mathrm{N}$ was greatly influenced by rainfall amount as well as sample size and variability in concentration. Significant correlation and high degree of association $(\mathrm{p} \leq 0.05)$ were obtained between the two species during the growing season. On the other hand inverse correlation and low association were recorded during the early and very late rains. Most of the values (about $75 \%$ ) of $\mathrm{NH}_{4}{ }^{+}-\mathrm{N}$ : $\mathrm{NO}_{3}{ }^{-}-\mathrm{N}$ ratios were in the range of $1-10$ while the overall amount-weighted mean was 3.4.

Annual and intraseasonal variations in the deposition of $\mathrm{NO}_{3}^{-}-\mathrm{N}, \mathrm{NH}_{4}{ }^{+}-\mathrm{N}$, and $\mathrm{TN}$ are shown in Table 2. For each species the monthly pattern of deposition was bimodal: the major mode occurred early in the season while the other mode coincided with the peak of rainfall. Most of the inputs occurred before and during the growing season. Fig. 2 and 3 are monograms relating isolines of $\mathrm{NH}_{4}{ }^{+}-\mathrm{N}$ and $\mathrm{NO}_{3}{ }^{-}-\mathrm{N}$ concentration values, respectively, each to both time and rainfall amount over the entire season.

TABLE 2

Nitrogen deposition in relation to farming season in the study area (Nigerian savanna)

$\begin{array}{lcccc}\text { Nitrogen per compound } & \begin{array}{c}\text { Annual } \\ \text { deposition }\end{array} & \begin{array}{c}\text { Early season } \\ \text { (March-May) }\end{array} & \begin{array}{c}\text { Growing season } \\ \text { (June }- \text { September) }\end{array} & \begin{array}{c}\text { Late season } \\ \text { (October \& November) }\end{array} \\ \mathrm{NO}_{3}^{-}-\mathrm{N}, \mathrm{kg} \mathrm{ha}^{-1} & 0.69 & 0.34(49.3 \%) & 0.26(37.7 \%) & 0.09(13.0 \%) \\ \mathrm{NH}_{4}^{+}-\mathrm{N}, \mathrm{kg} \mathrm{ha}^{-1} & 2.55 & 1.08(42.4 \%) & 1.26(49.4 \%) & 0.21(8.2 \%) \\ \mathrm{TN}, \mathrm{kg} \mathrm{ha}^{-1} & 3.24 & 1.42(43.8 \%) & 1.52(46.9 \%) & 0.30(9.3 \%)\end{array}$




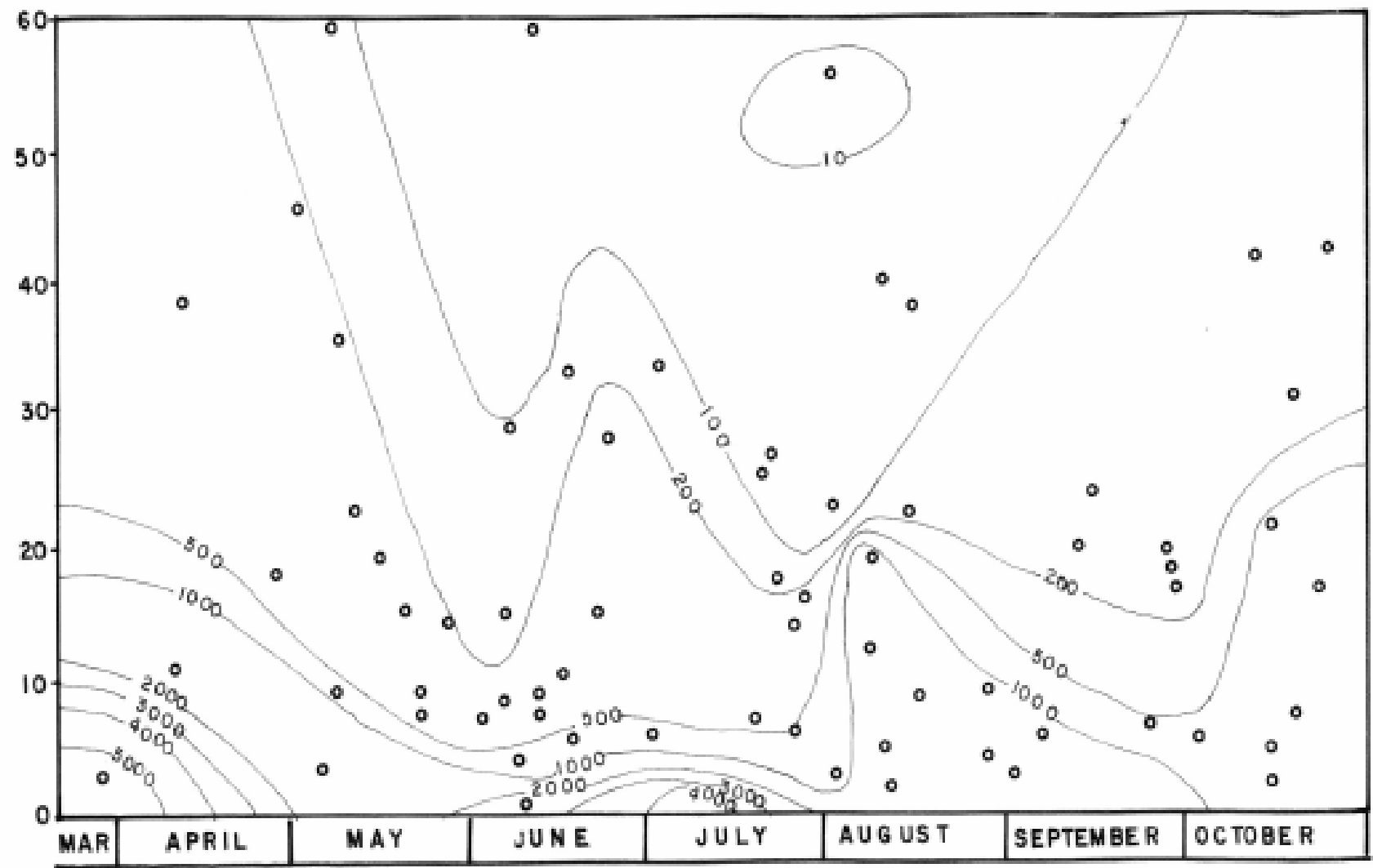

Fig. 2. Monogram showing isolines of ammonium-nitrogen $\left(\mathrm{NH}_{4}{ }^{+}-\mathrm{N}\right)$ concentration $\left(\mu \mathrm{gl}^{-1}\right)$ in relation to event rainfall amount $(\mathrm{mm})$ and time of the rainy season at Shagunu Research Station, Nigeria. 
West Africa Journal of Applied Ecology (WAJAE) -ISSN: 0855-4307

Volume 9 (Jan - Jun 2006)

www.wajae.org
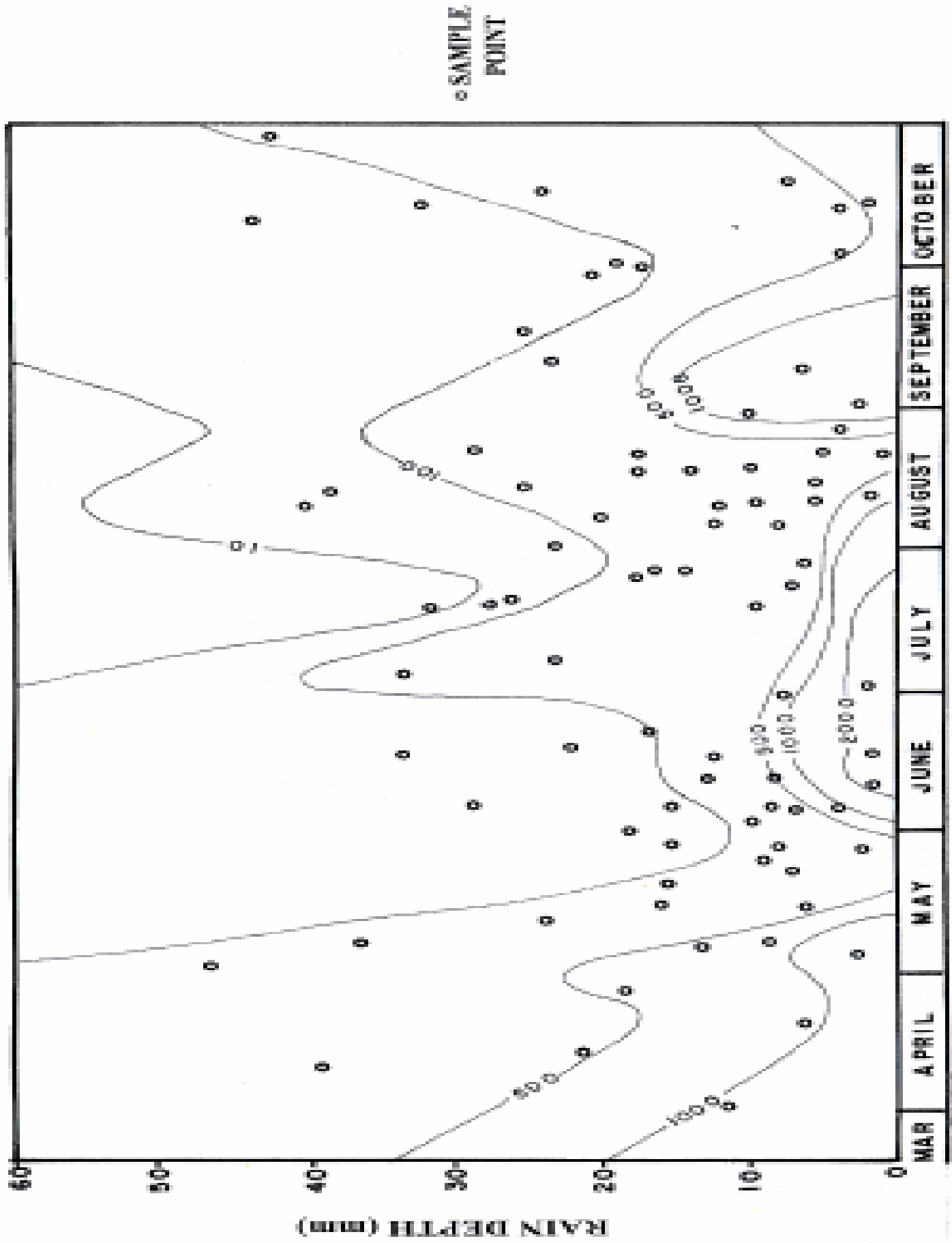

클

Fig. 3. Monogram showing isolines of nitrate-nitrogen $\left(\mathrm{NO}_{3}-\mathrm{N}\right)$ concentrations $\left(\mu \mathrm{gl}^{-1}\right)$ in relation to event rainfall amount (mm) and time of the rainy season at Shagunu Research Station, Nigeria

Nitrogen in relation to rainfall characteristics and water quality

Light rains (less $2 \mathrm{~mm} / \mathrm{h}$ ) and showers had much higher mineral-nitrogen concentra-tions than heavy rains (> 7 $\mathrm{mm} / \mathrm{h}$ ) and concentration decreased with shower size in an approximately exponential manner. Each of the three 


\section{West Africa Journal of Applied Ecology (WAJAE) -ISSN: 0855-4307 \\ Volume 9 (Jan - Jun 2006) \\ www.wajae.org}

nitrogen species showed highly significant direct correlation $(\mathrm{p} \leq 0.001)$ with rain conductivity and IBRE but inverse weak correlation with rainfall duration and intensity. While $\mathrm{NO}_{3}{ }^{-}-\mathrm{N}$ and $\mathrm{TN}$ each showed direct and highly significant correlation with $\mathrm{pH}, \mathrm{NH}_{4}^{+}-\mathrm{N}$ showed weak negative correlation with it.

The ratio of $\mathrm{NH}_{4}^{+}-\mathrm{N}$ : $\mathrm{NO}_{3}{ }^{-}-\mathrm{N}$ was inversely correlated with $p \mathrm{H}$ (for instance the average ratio at $\mathrm{pH}<6.3$ was 4.87 while at $p \mathrm{H}>6.6$ it was 1.37, and 2.2 for the intervening $p \mathrm{H}$ values of 6.3-6.6) as well as conductivity (at conductivity less $10 \mu \mathrm{sm}^{-1}$ the mean ratio was 2.2 as against the values of 0.80 and 0.16 over the ranges of 10.1-20, and $>20 \mu \mathrm{sm}^{-1}$, respectively).

\section{Comparative level of nitrogen input}

\section{Discussion}

In assessing the importance of nitrogen input in the study area the data obtained in the present study are compared with the available records for other parts of the Nigerian savanna during the growing season (Jones \& Bromfield 1970), the annual input in other parts of West Africa (Table 3), other parts of the tropics (Galbally \& Gillet, 1988; Sanhuexa et al, 1988) as well as some remote parts of the world (Galloway, 1985). This comparison reveals that nitrogen deposition in the study area was very low and similar only to values obtained for the remote continental areas of the world.

TABLE 3

Nitrogen deposition via direct bulk precipitation in West Africa

\begin{tabular}{|c|c|c|c|c|c|c|c|c|c|}
\hline \multirow[t]{2}{*}{ Study site } & \multirow[t]{2}{*}{ Country } & \multirow[t]{2}{*}{$\begin{array}{r}\text { Vegetation zone } \\
\text { position, }\end{array}$} & $\begin{array}{l}\text { Latitudinal } \\
\text { (N) from the }\end{array}$ & \multicolumn{2}{|c|}{$\begin{array}{l}\text { Distance Annual } \\
\text { rainfall, A }\end{array}$} & \multicolumn{3}{|c|}{$\begin{array}{l}\text { Annual nitrogen } \\
\text { deposition }\left(\mathrm{kg} \mathrm{ha}^{-1}\right)\end{array}$} & \multirow[t]{2}{*}{ Reference } \\
\hline & & & sea, $D(\mathrm{~km})$ & $(\mathrm{mm})$ & $\mathrm{NO}_{3}-\mathrm{N}$ & $\mathrm{H}_{4}-\mathrm{N}$ & $T N$ & & \\
\hline Unspecified & Gambia & Savanna & $13^{\circ} 20^{\prime}$ & 218 & $800 *$ & $3.6^{*}$ & $10.6^{*}$ & 14.2 & Thorton 1965 \\
\hline Samaru & Nigeria & Savanna & $11^{\circ} 11^{\prime}$ & 800 & 886 & 0.25 & $34.9 * * ?$ & $34.9 * * ?$ & Jones 1960 \\
\hline Samaru & Nigeria & Savanna & $11^{\circ} 11^{\prime}$ & 800 & 1218 & 2.1 & 2.5 & 5.6 & Jones 1971 \\
\hline Shagunu & Nigeria & Savanna & $10^{\circ} 28^{\prime}$ & 440 & 925 & 0.7 & 2.6 & 3.3 & This study \\
\hline Lamto & Cote d'Ivoire & Savanna & $06^{\circ} 13^{\prime}$ & 120 & 1300 & 2.3 & $9.2^{*}$ & $11.5^{*}$ & Villencourt 1975 \\
\hline Lamto & Cote d'Ivoire & Savanna & $06^{\circ} 13^{\prime}$ & 120 & 1250 & 1.3 & 6.5 & 7.8 & Villencourt 1975 \\
\hline Unspecified & Gambia & Forest (marsh) & $13^{\circ} 20^{\prime}$ & 15 & 1500 & $7.2^{*}$ & $39.8 *$ & 47.0 & Thorton 1965 \\
\hline $\begin{array}{l}\text { Ile-Ife } \\
1995\end{array}$ & Nigeria & Forest & $07^{\circ} 28$ & 130 & 1950 & 4.8 & 38.5 & 43.3 & Isichei et al. \\
\hline $\begin{array}{l}\text { Trho/Lamto } \\
1984\end{array}$ & Cote d'Ivoire & Forest & $06^{\circ} 00^{\prime}$ & $80 *$ & 1309 & 4.0 & 10.0 & 14.0 & Servant et al. \\
\hline Kade & Ghana & Forest & $05^{\circ} 30^{\prime}$ & 100 & 1400 & 2.5 & 11.5 & 14.0 & Nye 1961 \\
\hline $\begin{array}{l}\text { Ororokpe } \\
\text { (unpublished }\end{array}$ & Nigeria & Forest (swamp) & $05^{\circ} 36^{\prime}$ & 80 & 2160 & 7.2 & $\begin{array}{l}41.7 \\
\text { data) }\end{array}$ & 48.9 & Adeniyi \\
\hline stimlat & & & & & & & & & \\
\hline
\end{tabular}

Analysis of data in Table 3, however, shows that the annual magnitude of total inorganic nitrogen deposition in West Africa (excluding questionable figures) is over a wide range of $0.25-48.9 \mathrm{~kg} \mathrm{ha}^{-1}$ comprising $0.25-7.2 \mathrm{~kg}$ $\mathrm{ha}^{-1} \mathrm{NO}_{3}^{-}-\mathrm{N}$ and $0.7-4.0 \mathrm{~kg} \mathrm{ha}^{-1} \mathrm{NH}_{4}^{+}-\mathrm{N}$. At 95\% confidence interval, the mean annual range of deposition over the two vegetation zones are as follow: $0.7-2.7 \mathrm{~kg} \mathrm{ha}^{-1} \mathrm{NO}_{3}^{-}-\mathrm{N}, 2.8-9.6 \mathrm{~kg} \mathrm{ha}^{-1} \mathrm{NH}_{4}^{+}-\mathrm{N}$ and $6.4-12.4 \mathrm{~kg} \mathrm{ha}^{-1}$ total nitrogen (savanna zone) and 3.2-7.0 kg ha-1 $\mathrm{NO}_{3}^{-}-\mathrm{N}, 14.0-42.6 \mathrm{~kg} \mathrm{ha}^{-1} \mathrm{NH}_{4}^{+}-\mathrm{N}$, and 17.4-49.4 kg ha-1 total nitrogen (forest zone). Thus, area deposition is much higher in the forest than in the savanna with overall 


\section{West Africa Journal of Applied Ecology (WAJAE) -ISSN: 0855-4307 \\ Volume 9 (Jan - Jun 2006) \\ www.wajae.org}

mean forest savanna deposition ratio of 3:1 $\left(\mathrm{NO}_{3}^{-}-\mathrm{N}\right), 4.5: 1\left(\mathrm{NH}_{4}^{+}-\mathrm{N}\right)$ and 4:1 (total nitrogen). Similarly, the average deposition ratio of $\mathrm{NH}_{4}{ }^{+}-\mathrm{N}: \mathrm{NO}_{3}{ }^{-}-\mathrm{N}$ of about 5.5:1 in the forest: is much higher than the value of 3.7:1 in the savanna. In general, the spatial pattern of variation over the entire West Africa region is such that deposition is negatively correlated with latitude and distance away from the sea along the north-south axis but positively correlated with annual rainfall amount. It is possible to estimate annual deposition of $\mathrm{NO}_{3}{ }^{-}-\mathrm{N}, \mathrm{NH}_{4}^{+}-$ $\mathrm{N}$ and total- $\mathrm{N}$ in the region from the three variables applying the following linear multiple regression equations: $\mathrm{NO}_{3}^{-}-\mathrm{N}\left(\mathrm{kgha}^{-1}\right)=4.04 \times 10^{-3} \mathrm{~A}+0.47 \mathrm{~L}-4.3 \times 10^{-3} \mathrm{D} 5.41$

$\left(\mathrm{R}^{2}=0.914, \mathrm{P}=0.0006, \mathrm{df}=3 \& 7\right)$.

$\mathrm{NH}_{4}^{+}-\mathrm{N}\left(\mathrm{kgha}^{-1}\right)=0.039 \mathrm{~A}+3.05 \mathrm{~L}-0.025 \mathrm{D} 54.45$

$\left(\mathrm{R}^{2}=0.994, \mathrm{P}=0.000 \mathrm{df}=3 \& 6\right)$.

Total- $\mathrm{N}(\mathrm{kgha})=0.043 \mathrm{~A}+3.50 \mathrm{~L}-0.028 \mathrm{D}-61.01$

$\left(\mathrm{R}^{2}=0.995, \mathrm{P}=0.0000, \mathrm{df}=3 \& 6\right)$

where $\mathrm{A}=$ total annual rainfall amount $(\mathrm{mm}), \mathrm{L}=$ latitudinal position (minute being expressed as a fraction of one degree, e.g. $\left.10^{\circ} 28^{\prime}=10.47^{\circ}\right), \mathrm{D}=$ distance away from the sea $(\mathrm{km}), \mathrm{R}^{2}=$ coefficient of determination, $\mathrm{P}=$ probability of chance, and $\mathrm{df}=$ degree of freedom.

Based on the above equations, about $50 \% \mathrm{NO}_{3}^{-}-\mathrm{N}, 100 \% \mathrm{NH}_{4}{ }^{+}-\mathrm{N}$, and $100 \%$ total nitrogen were actually realized in the study area. This suggests that although deposition values were low, they were in accordance with expectations with regard to position and rainfall amount at the study site.

The preceding analysis implies low background levels of nitrogen not only in the study area but in the Nigerian savanna as a whole and suggests limited and/or low nitrogen sources, otherwise inefficient mechanisms of production fluxes. Although the sources of atmospheric fixed nitrogen are now fairly well known (Soderlund \& Svensson, 1976; Crutzen et al., 1985) there is little actual information on this in West Africa. Evidence from Jones \& Wild (1975), Isichei \& Sanford (1980) as well as Singh \& Balasabramania (1980) also shows that annual bush burning is the most important source of nitrogen input to the atmospheric environment of natural Nigerian savanna. Annual bush burning caused accidentally (by spontaneous combustion or by lightning) or intentionally by pastoralists and farmers is very rampant in Nigerian savanna during the dry season, particularly from December to February. Based on above-ground herbaceous materials and litter fall prior to burning, Isichei \& Sanford (1980) estimated an annual mean of 13 (range = 12-15) kg Nha ${ }^{-1}$ loss in bush burning.

Volatilization of ammonia from animal wastes and products (including man and livestock) has been suggested as the main source of atmospheric ammonia in remote areas (Galbally et al., 1980). Depending on the environment, significant input of various fixed nitrogen species can also be derived from various biological activities (notably nitrogen fixation, ammonification, nitrification and denitrification) in both terrestrial and aquatic ecosystems. Emission from volcanoes and natural atmospheric phenomena (e.g. photooxidation by lightning) can also be important. However, nitrogen input potential from these sources are considered low in the study area (Lake Kainji area) for a number of reasons: The area is thinly populated and non industrialized and like most parts of the Nigerian Middle-Belt, livestock population is equally low due to the serious problems of tsetse fly (Glossina species) attack. The soils which are mostly sandy are generally poor in nitrogen (Jones, 1973) with mean $p \mathrm{H}$ only slightly above 6.0 (Klinkenberg \& Hilderband, 1964).

The application of fertilizer of any sort is very low as agriculture is carried out only at subsistence level. Lake Kainji is oligotrophic and only slightly alkaline (Adeniyi, 1978) while recent alluvial deposits are only of very subordinate importance in that these occupy very limited and irregular areas amidst rocky and strong terrain in stream valley areas (Valette, 1973). Although there is considerable abundance of legumes in the Nigerian savanna, consisting about $17.4 \%$ of woody species (Obot, 1980), Nye \& Greenland (1960) believed that native woody legumes in the savanna do not fix nitrogen. According to Bond $(1967,1977)$ only two genera (Casuarina and Trema) of the 14 non-legumes which form association with bacteria of the Order Actionmycetes which are known to fix nitrogen occur in West Africa. 


\section{West Africa Journal of Applied Ecology (WAJAE) -ISSN: 0855-4307 \\ Volume 9 (Jan - Jun 2006) \\ www.wajae.org}

The low annual deposition in the study area can also be attributed to the low annual rainfall (95\% confidence intervals $=850-900 \mathrm{~mm}$ ) which due to topographical situation is much lower than those of many towns which are much farther up in the savanna. It may also be due to lack of any important long range source input, except perhaps the harmattan dust from the Sahara desert (Adetunji \& Ong,1989).

\section{Variability in nitrogen levels and temporal trends}

One prominent feature of nitrogen concentration and deposition in the present study was the wide variability exhibited in individual samples and in temporal trends. While samples with very high concentrations of nitrogen were not limited to any particular period of the season the temporal pattern were characterized by highest/generally high values during early rains and the lowest/generally low values in mid season or at the peak of the season. Such large individual and temporal variability has been shown to have profound effect on species correlation and ratios (i.e. $\mathrm{NO}_{3}^{-}-\mathrm{N}$ and $\mathrm{NH}_{4}^{+}-\mathrm{N}$ ) and illustrates the large errors that may be involved when estimates of annual fluxes are based only upon small temporal samples (Kellyman et al. 1982). More importantly, influx variability reveals an aspect of temporal environmental heterogeneity in the tropics that has received little attention in the literature (Kellyman et al., 1982).

The temporal patterns shown by $\mathrm{NO}_{3}-\mathrm{N}$ and $\mathrm{NH}_{4}{ }^{+}-\mathrm{N}$ in the present study are, respectively, similar to those shown by $\mathrm{NO}_{3}^{-} \mathrm{N}$ and $\mathrm{NH}_{4}^{+}-\mathrm{N}$ in surface soil $(0-15 \mathrm{~cm}$ ) at Ibadan, in the derived savanna of Nigeria (Juo, 1980). Juo (1980) found considerable seasonal fluctuation in the level of these two parameters in both fallow and cultivated soils and noted that nitrate level remained high during the first part of the rainy season, indicating a flush in nitrogen mineralization at the onset of the rainy season. Probably this, and the many indirect effects of bush burning such as increased soil alkalinity, reduced $\mathrm{C} / \mathrm{N}$ ratio and increased microbial activities (Daubenmire, 1968, Viro, 1974) are likely to be responsible for the high concen-trations and influx of nitrogen during the early rainy season.

The strong positive correlations between $\mathrm{NO}_{3}{ }^{-}-\mathrm{N}$ and $\mathrm{NH}_{4}{ }^{+}-\mathrm{N}$ during mid rainy season reflect the mutual reduction in their levels due to decreased particulate matter but increased rain intensity, and precipitable water and washout during this period. Although the soil water and relative humidity are much higher during this period, the preponderance of well drained sandy soil, low organic matter content and increased acidity (which also prevails at this time) are not likely to make nitrogen emission on a regional basis of importance. This is unlike the observation of Servant et al. (1984) in the forest region of Cote d'Ivoire where at the peaks of the rains the soils were flooded leading to increased ammonification and decrease in nitrification.

The fact that $\mathrm{NO}_{3}^{-}-\mathrm{N}$ and $\mathrm{NH}_{4}^{+}-\mathrm{N}$ were each very highly significantly correlated with rainwater conductivity shows a common origin of nitrate, ammonium and the major ions in rainwater. Visser (1964) obtained the same results for rainwater at Kampala (Uganda) and his investigation revealed that dust was the primary source of the nutrients. The same has been suggested by several other workers (Junge, 1958). All these and other evidence tend to suggest that rainwater inorganic nitrogen in the study area is mostly of terrestrial origin, with bush burning and harmattan dust as the major sources. Thus, as noted for some other remote sites in the tropics (Wessallar, 1980) rainwater nitrogen in Lake Kainji is most probably only a part of the terrestrial cycle and cannot be regarded as true accession.

It is also of interest to know how much of nitrogen input into the atmosphere or total annual input into the ecosystem was returned via direct bulk precipitation. Such computations are difficult for lack of adequate information. With regard to input through bush burning, information is lacking on the actual input (as opposed to the estimates now often used) and the identity and relative proportion of the different nitrogen species $\left(\mathrm{N}_{2}\right.$, $\mathrm{NO}, \mathrm{N}_{2} \mathrm{O}, \mathrm{NH}_{3}$, or even $\mathrm{HCN}$ and $\mathrm{CH}_{3} \mathrm{CO}_{2}=\mathrm{PAN}$ ) that are likely to be present. 


\section{West Africa Journal of Applied Ecology (WAJAE) -ISSN: 0855-4307 \\ Volume 9 (Jan - Jun 2006) \\ www.wajae.org}

The results of the present study suggest that only about $25 \%$ (consisting of $5 \% \mathrm{NO}_{3}^{-}-\mathrm{N}$ and $20 \% \mathrm{NH}_{4}^{+}-\mathrm{N}$ ) of the estimated $13 \mathrm{~kg} \mathrm{~N} \mathrm{ha}^{-1}$ loss via bush burning was returned in bulk precipitation. This low return may be due to low washout factor, loss beyond the cloud altitude or far away from source input. It could also be due to uptake by vegetal surface or occurrence in none or sparingly soluble forms. Considering the low soil nitrogen content and its annual rate of mineralization of only $4 \%$ in the study area, nitrogen input via bulk precipitation which is about $12 \%$ of the estimated input of $25 \mathrm{~kg} \mathrm{~N} \mathrm{ha}^{-1}$ for Nigerian grazing savanna (Penning de Vries, 1980) is still considered important.

\section{Acknowledgement}

The author would like to acknowledge the assistance of Mr Lawrence Aboh Unogwu of the National Institute for Freshwater Fisheries Research, Shagunu Research Station, Nigeria, for his assistance in sample collections.

\section{References}

Adeniyi I. F. (1978). Studies of the physico-chemical factors and the planktonic algae of Lake Kainji. (PhD. Thesis.) Obafemi Awolowo University, Ile Ife, Nigeria. 597 pp.

Adetunji J. and Ong C. K. (1989). The concentration of trace elements in the Harmattan haze. Discovery and Innovations 1(1): 63-66.

Afolayan T. A. (1982). Climate of study Area. In Nigerian savanna; selected papers from the Man and Biophere State-of-knowledge Workshop. (W. W. Sanford, H. M. Yesufu and J. S. O. Ayeni, ed.), pp. 234-240. .

Allen S. E., Grimshaw A. H. M., Parkinson J. A. and Quarmby C. (1974). Chemical Analysis of Ecological Materials. Blackwell Scientific Publications, Oxford.

American Public Health Association (APHA) (1980). Standard methods for the examination of water and waste-water, 15th edn. New York.

Berg P. Nwoboski L. C. Adedipe N. O. and Rosswall T. (1980). References to publications on nitrogen cycling in West African Ecosystems. In Nitrogen Cycling in West African Ecosystems. (T. Rosswall, ed.), p. 429-447. SCOPE, Inter-national Nitrogen Unit, Stockholm, Sweden.

Bond G. (1967). Fixation of nitrogen by higher plants other than legumes. A. Rev. Pl. Physiol. 18:107-126.

Bond G. (1977). Some reflections on Alnus-type nodules. In Recent developments in nitrogen fixation. (W. Newton, J. R. Postage and C. Rodriquez-Bamieco, ed.), pp. 531-537. Academic Press, London.

Chaney A. L. and Marbach E. P. (1962). Modified reagents for determination of urea and ammonia. Clin. Chem. 8: 130-132.

Clayton W. D. (1957). Some notes on vegetation recording at Mokwa. (Unpublished report). Ministry of Agriculture, Samaru, Nigeria.

Crutzen P. J., Delany A. C., Greenberg J., Haagenson R., Heidt L., Lueb R., Pollock N., Seller W., Wartburg A. and Zimmerman P. (1985). Tropospheric chemical composition measurements in Brazil during the dry seasons. J. Atmos. Chem. 2: $233-256$.

Daubenmire R. (1968). Ecology of fire in grassland. Adv. ecol. Res. 5: 209-266.

El-Zarka S. E. D. (1973). Kainji Lake, Nigeria. In Man-made lakes, their problems and environmental effects. Geophys. Monogr. Ser. 17. (W. C. Ackermann, G. F. White and E. B. Worthington, ed.), pp. 197-219. American Geophysical Union. Washington D.C.

Galbally I. E., Freney J. R., Denmead O. T. and Roy C. R. (1980). Processes controlling the nitrogen cycle in the atmosphere over Australia. In Biogeochemistry of ancient and Modern Environments. (P. A. Frudinger, M. R. Walter and B. J. Ralph, ed.) Australian Academy of Science, Camberra.

Galbally I. E. and Gillet R. W. (1988). Processess regulating nitrogen compounds in the tropical atmosphere. In Acidification in Tropical Countries. (H. Rodhe and R. Herrera., ed.), pp. 73-116. Scope 36. John Wiley, Chichester. New York.

Galloway J. N. (1985). The deposition of sulphur and nitrogen from the remote atmosphere-background. In The Biologeochemical cycling of sulphur and nitrogen in the remote atmosphere. (J. N. Galloway, R. J. Charison M. Anireae and H. Rodhe, ed.), pp. 143-175. Reidah Publishing Company.

Gras J. L. (1983). Ammonia and ammonium concentrations in the Antarctic atmosphere. Atmos. Envir. 17: 815-818.

Henderson R. F. (1973). A limnological description of Kainji Lake. FOA. Technical Report F.J. DP/NIR/66/524/10. Rome, FOA.

Hutchinson G. E. (1957). A treatise on Limnology, vol. 1, pp. 17-26. John Wiley. New York.

Imevbore A. M. A. (1970). Some general features of the Kainji Reservoir Basin. In Kainji a Nigerian Man-made Lake: Kainji Lake Studies, vol. 1. (S. A. Visser, ed.), pp. 17-26. University of Ibadan Press, Nigeria.

Isichei A. O. (1995). Stocks of nitrogen in vegetation and soil in West African moist savannas and potential effects of climate change and land use on these stocks. J. Biogeogr. 22: 393-399.

Isichei A. O., Morton A. and Ekeleme F. (1990). Mineral nutrient flow from an inselberg in southwestern Nigeria. J. trop. Ecol. 6 (6): 479-492.

Isichei A. O. and Sanford W. W. (1980). Nitrogen loss by burning from Nigerian grassland ecosystems. In Nitrogen cycling in West African Ecosystems. (T Rosswall, ed.), pp. 325-331. SCOPE International Nitrogen Unit, Stockholm, Sweden.

Jones E. (1960). Contribution of rainwater to the nutrient economy of soil in northern Nigeria. Nature, Lond. $188: 432$.

Jones M. J. (1971). Ammonium and nitrate nitrogen in the rainwater at Samaru, Nigeria. Tellus 23 (4-5): 459-461.

Jones M. J. (1972). Ammonium and nitrate nitrogen in the rainwater at Samaru, Nigeria. Samaru Res. Bull. 159.

Jones M. J. (1973). The organic matter content of the savanna soils of West Africa. J. Soil Sci. 24: 42-53.

Volume 9 (Jan - Jun 2006)

Page 11 of 12 


\section{West Africa Journal of Applied Ecology (WAJAE) -ISSN: 0855-4307 \\ Volume 9 (Jan - Jun 2006) \\ www.wajae.org}

Jones M. J. and Bromfield A. R. (1970). Nitrogen in the rainfall at Samaru, Nigeria. Nature, Lond. 227: 86.

Jones M. J. and Wild A. (1975). Soils of the West African Savanna. Technical Communication No. 55. Commonwealth Agricultural Bureau, Slough, U.K.

Junge C. E. (1958). The distribution of ammonia and nitrate in rainwater over the United States. Trans. Am. geophys. Un. 39:241-248.

Junge C. E. (1963). Air Chemistry and Radioactivity. Academic Press, New York.

Juo A. S. R. (1980). Nitrogen profile in a kaolinitic alfisol under fallow and continuous cultivation. In Nitrogen Cycling in West African Ecosystem. (Rosswall T., ed.), pp. 181-190. SCOPE International Nitrogen Unit, Stockholm, Sweden.

Keay R. W. J. (1959). An outline of Nigerian vegetation, 3rd edn. Government Printer, Lagos, Nigeria. 46 pp. + maps.

Kellyman M., Hudson J. and Sanmugadas F. H. (1982). Temporal variability in atmospheric nutrient flux to at tropical cosystems. Biotropica 14 (1): 1-9.

Klinkenberg K. and Hilderbrand, F. H. (1964). Report on the semi-detailed soil survey of areas near the new town-site of Bussa (Niger Dam Ressertlement Project). Soil Survey Bulletin No. 27, Institute of Agricultural Research, Ahmadu Bello University Samaru, Zaria, Nigeria.

National Academy of Sciences (1969). Entrophication: Causes, Consequences, Correctives - Proceedings of a Symposium. Washington D.C. 661 pp.

McConnell J. C. (1973). Atmospheric ammonia. J. geophys., Res. 78 (33): 7812-7821.

Nye P. H. (1961). Organic matter and nutrient cycles under moist tropical forest. Pl. Soil 13:333-346.

Nye P. H. and Greenland D. J. (1960). The soil under shifting cultivation. Technical Communica-tion No. 51, Commonwealth Bureau of Soils, Bucks, England.

Obot E. O. (1980). Input and cycling of nitrogen via rainfall under savanna conditions in south-western Nigeria. (MSc. Thesis.) Obafemi Awolowo University, Ile-Ife, Nigeria. 61 pp.

Papadakis J. (1965). Crop ecology survey in West Africa (Liberia, Ivory Coast, Ghana, Togo, Dahomey, Nigeria), vol. II. Atlas, FAO., Rome.

Penning De Vries F. W. T. (1980). Report of the work group on the Sahel-Savanna Zone. In Nitrogen Cycling in West African Ecosystems. (T Rosswall, ed.), pp. 399-407. SCOPE Inter-national Nitrogen Unit, Stockholm, Sweden.

Reiter R. and Reiter M. (1958). Relations between the contents of nitrate and nitrite ion in pre-cipitation and simultaneous atmospheric electric processes. In Recent Advances in Atmospheric Electricity. L. G. Smith, ed.), pp. 175. Pergamon Press, London.

Robertson G. P. and Rosswall T. (1980). Nitrogen in West Africa: The regional cycle. Ecol. Monogr. 56(1): $43-72$.

Sanhuexa E, Cuenca Ca., Comez M.J ., Herrera R., Ishizaki C., Marti J. and Paolini J. (1988). Characterization of the Venezuelan environment and its potential for acidification. In Acidification in Tropical Countries. (H. Rodhe and R. Herrare, ed.), pp. 197255. SCOPE 36 John Wiley and Sons, Chichester, England.

Servant J., Delmas R., Rancher J. and Rodrigvez M. (1984). Aspects of the cycle of inorganic nitrogen compounds in the Tropical rain forest of the Ivory Coast. J. Atmos. Chem. 1: 391-401.

Singh A. and Balasabramanian V. (1980). Nitrogen cycling in the savanna zone of Nigeria. In Nitrogen Cycling in West African Ecosystems. (T. Rosswall, (ed.), pp. 371-391. SCOPE International Nitrogen Unit. Stockholm, Sweden.

Soderlund R. and Svensson B. H. (1976). The global nitrogen cycle. In Nitrogen, phosphorus and Sulphur-Global cycles. (B. H. Svensson and R.Soderlund, ed.), pp. 23-73. SCOPE 7. Ecol. Bull. Stockholm.

Thornton I. (1965). Nitrogen content of rainwater in the Gambia. Nature, Lond. 205: 1025.

Valette J. (1973). The reconnaissance soil survey of the Mokwa-Kontagora and Kainji area, North-western and Kwara States, Nigeria. Soil Surv. Bull. 44. Institute of Agricultural Research Samaru, Ahmadu Bello University, Nigeria.

Visser S. A. (1964). Origin of nitrates in tropical rainwater. Nature, Lond. 201: 35-36.

Villencourt P. (1975). Deposition of mineral nitrogen by rain in Lamto Savanna. Rev. Ecol. biol. Sci. 12 (4): 667-680.

Viro P.J. (1974). Effects of forest fire on soil. In Fire and Ecosystems. (T. T. Kozlowski and C. E. Ahlgren, ed.), pp. 7-44. Academic Press, New York.

Westsallaar R. (1980). Nitrogen cycling in a semi-arid region of tropical Australia.In Nitrogen Cycling in West African Ecosystems. (Rosswall T., ed.), pp. 157-160. SCOPE International Nitrogen Unit, Stockholm. Sweden.

White F. (1983). Vegetation Map of Africa. UNESCO/EATFAT/UNSO. Paris, France.

Whitehead H. G. and Feth J. H. (1964). Chemical composition of rain, dry fallout and bulk precipitation at Menlo Park, California, 1957-1959. J. geophys. Res. 69: 3319-3333. 